\title{
Exploration, Isolation, and Identification of Carotenoid from Bacterial Symbiont of Sponge Callyspongia vaginalis
}

\author{
Iqna Kamila Abfa ${ }^{1}$, Ocky Karna Radjasa ${ }^{2}$, AB Susanto ${ }^{2}$, Handung Nuryadi² and Ferry F. Karwur ${ }^{1 *}$ \\ ${ }^{1}$ Graduate School of Biology Satya Wacana Christian University \\ Jl. Diponegoro No. 52-60 Salatiga Indonesia 50711 \\ ${ }^{2}$ Faculty of Fisheries and Marine Science Diponegoro University \\ Jl. Prof. H. Soedharto, SH. Tembalang Semarang 50275 \\ Email: fkarwur@yahoo.com
}

\begin{abstract}
During the past two decades research on marine bacteria has highlighted the tremendous potential of symbioticmicroorganisms as a source of bioactive secondary. One of the potential of the bacterial symbionts is producing a natural pigment, and these organisms can be used as a sustainable source of natural pigments. Carotenoid is one of the most important pigments that has important roles in physiological and molecular processes of microorganisms, as well as for human health. The objective of this study is to analyze carotenoid pigments from marine bacterial symbionts from sponge and to identify bacterial symbionts that produce carotenoid pigments. Pigment analysis was performed by a UV-VIS spectrophotometer and High Performance Liquid Chromatography (HPLC). Molecular bacterial identification was performed based on $16 S$ rDNA sequence. The isolation of bacterial symbionts from C. vaginalison Zobell 2216E medium resulted in one bacterium, CB-SP5, positively synthesized carotenoids. By reverse phase HPLC analysis, the carotenoid pigments in the bacterial symbionts were identified as diadinoxanthin, fucoxanthin, neoxanthin, dinoxanthin, and diadinochrome. CB-SP5 shared the highest level of $16 S$ rDNA gene sequence similarity with Psychrobacter celer(99\%).
\end{abstract}

Keywords : carotenoid, sponge, bacterial symbiont, 16S rDNA.

\section{Introduction}

Sponges contribute significantly to the total fauna of sessile marine organisms worldwide and dominate the benthic community of some Caribbean and other tropical waters. They are filter-feeding animals because all adult sponges are sessile and cannot move around benthic surface (Hentschel et al., 2002). Various organisms have been found in sponges, including a diverse range of green algae, heterotrophic bacteria, cyanobacteria, archea, cryptophytes, red algae, dinoflagellates and diatoms. One host sponge can possess diverse symbionts. Large numbers of bacteria are also known to be harboured within the extracellular mesophyl matrix of many sponges, living in symbiosis with their host (Imhoff and StÖhr, 2003), or production of secondary metabolites (Unsonet al., 1994).

Many of the heterotrophic bacteria that synthesize carotenoids have been isolated from coastal and oceanic waters (Du et al. 2006; Satfsnes et al., 2006). Some of these bacteria may serve beneficial purposes as the sources of secondary metabolites including marine natural products, such as natural pigments (Radjasa et al.,
2003). The accumulating evidences indicate that many bioactive compounds from marine invertebrates are indeed produced by bacterial symbionts (Radjasa et al., 2009). Through the years, pigments have been used as a taxonomic tool for the identification and classification of algae, fungi, and bacteria. The most widely distributed pigments are the carotenoids (Cardona et al., 2010). That also play an important role in bacteria, such as in preventing photo-damage during photosynthetic processes, and conferring resistance to oxidative damage due to the production of oxygen (Harashima, 1989; Takaichi et al.,1990).

Carotenoids are yellow to red coloured pigments which originate from terpenoid biosynthetic pathway, and are synthesized by plants, algae and by some fungi and bacteria. They are involved in the photosynthesis as accessory pigments, functioning as antioxidants, light protection pigments and membrane stabilizer (Abdelnasser, 2008). The most important biological function of carotenoids is as antioxidants owing to their potential to inactive singlet oxygen and to quench carboxyl radicals (Di Mascio et al., 1989; Burton and Ingold, 1984; Britton, 1995). 
Bacteria isolated from living surfaces, in particular from sponge are a promising source of natural products. Symbiotic marine bacteria with this sponge also have the potential to produce natural pigments (Wusqy et al., 2014). Carotenoid pigment is very feasible to be exploredue to the excellence and diversity of marine microorganisms. In this work, we reported analysis of carotenoid pigments of marine bacterial symbiont from sponge and molecular identification of bacterial symbiont that produce carotenoid pigments.

\section{Materials and Methods}

\section{Sampling and isolation of bacterial symbionts}

Samples of sponge Callyspongia vaginalis, were taken from Cemara Besar Island, Karimunjawa at depth of 5-10 meters manually by using a cutter, which were then put into sterile plastic bag and were stored temporarily in a cool box. The samples were rinsed 3 times with sterile sea water to clean the bacteria that temporarily attached to the surface waters. The tissues were then rinsed with sterile seawater and cut with a sterile knife. The resultant tissues were serially diluted, spread on full strength ZoBell 2216E marine agar medium and incubated at room temperature for $\pm 72 \mathrm{~h}$ (Burgess et al., 2003). Petri dish was then incubated at $30^{\circ} \mathrm{C}$ for three days. On the basis of morphological features, the colonies were randomly picked and purified by making streak plates (Madigan et al.,2000).

\section{Extraction of bacterial pigments}

Appearance of yellow pigment from the bacterium isolate was started after 72 hours of incubation in the culture medium. Bacterial symbiont was cultured on Zobell agar medium. A total of two grams of pellets were extracted using cold acetonemethanol $35: 15 \mathrm{ml}(7: 3 \mathrm{v} / \mathrm{v})$ (Cohen-Bazire et al., 1957; Kuki et al., 1994), with the aid of a sonicator (Britton, 1995). Afterwards, the pigments were then dried by the use of nitrogen $\left(\mathrm{N}_{2}\right)$ gas flow.

\section{Identification and analysis of pigment content}

Pigments were identified and analyzed by using High Performance Liquid Chromatography (HPLC) Shimadzu LC-20 in reversed phase column $A B$ with, $C 18$, having a diameter of $4 \mathrm{~mm} \times 25 \mathrm{~mm}$ and a mobile phase of methanol: acetone (Nugraheni et al., 2010). Detection of pigment was performed at a wavelength of $190-800 \mathrm{~nm}$ with a flow rate $1 \mathrm{ml} . \mathrm{min}-1$, pressure 1000 psi (Maeda et al., 2005).

\section{DNA Extraction of Bacterial symbiont}

The genomic DNA of bacterial symbiont was extracted by using Chelex 100. Bacterial symbiont pellet cells were added with $100 \mu \mathrm{l}$ of $\mathrm{dd} \mathrm{H}_{2} \mathrm{O}$. The mixture was then added with $1 \mathrm{ml}$ of $0.5 \%$ saponin in Phosphate-buffered saline (PBS) 1X, was allowed for an overnight temperature of $4^{\circ} \mathrm{C}$. The mixture was centrifuged at 12000 RPM for 10 minutes then $1 \mathrm{ml}$ of PBS $1 \mathrm{X}$ was added and centrifuged again at 12000 RPM for $5 \mathrm{~min}$. The mixture was added to $100 \mu \mathrm{l}$ of $\mathrm{ddH}_{2} \mathrm{O}$ and $50 \mu \mathrm{l}$ of $20 \%$ chelex 100. After that, the mixture was boiled for $10 \mathrm{~min}$ in hot water with temperature of $95^{\circ} \mathrm{C}$, and vortexed once after $5 \mathrm{~min}$. Subsequently, the mixture was run at 12000 RPM for $10 \mathrm{~min}$. The final concentration of the DNA was measured using Eppendorf tube, and then stored at - $20^{\circ} \mathrm{C}$ (Walsh et al., 2013).

\section{S rDNA Polymerase Chain Reaction}

The universal primer 27F (5'AGAGTTTGATCMTGGCTCAG-3') and primer 1492R (5'-TACGGYTACCTTGTACGACTT-3') were used to amplify 16S-rDNA gene (Long and Azam, 2001). The temperature cycle of amplification was as follows: initial denaturation at a temperature of $94^{\circ} \mathrm{C}$ for 2 $\mathrm{min}$, and then successive denaturation $\left(94^{\circ} \mathrm{C}\right.$ for 2 $\mathrm{min})$, annealing $\left(55^{\circ} \mathrm{C}\right.$ for $\left.1 \mathrm{~min}\right)$, and extension ( $72^{\circ} \mathrm{C}$ for $\left.2 \mathrm{~min}\right)$. Series of denaturation, annealing and extension were repeated until 45 cycles. Electrophoresis was done on $2 \%$ agarose. Sequencing was done according to Radjasa et al. (2009). Homology search and DNA data bank by BLAST (Altschul et al., 1997).

\section{DNA Sequencing Accession Number}

The complete 16S rDNA gene of bacterial isolate CB-SP5 have been determined and deposited in DDBJ. The GenBank accession number is LC214826.

\section{Results and Discussion}

\section{Sampling and isolation of bacterial symbionts.}

Microbial pigments are a promising alternative to other colour additives extracted from vegetables or animals because they are considered as natural and show high productivity (Rashid et al., 2014). The main and most plentiful pigment group in marine pigmented bacteria is carotenoid which usually appears orange, yellow or red colour (Marit et al., 2010). 
In this study, we have successfully isolated a bacterial symbiont of sponge Callyspongia vaginalis. Marine sponges are rich sources of natural compounds, which exhibit wide variety of biological activity (Ibrahim et al., 2014). C. vaginalis is a solitary species, play an important role in the transfer of energy between the benthic and pelagic environments on coral reefs (Duckworth et al., 2006; Cruickshank, 2016). It is also functionally important for water-column productivity, utilized in a saltwater aquarium to aid in the filtration of suspended food particles (Walters et al., 2005; Cruickshank et al, 2016).

Isolate CB-SP5 produce pigment which was expected as source of carotenoids. The bacterial gave a greenish yellow colour (Figure 1).

The carotenoids were extracted and identified based on their chemical, chromatographic and spectroscopic spectral (UV-Vis and mass spectrometry). Analysis by spectrophotometer is the step to identify the presence of pigment in bacterial symbiont of C. vaginalis. Absorption spectra UV spectrophotometer are shown in Figure 2.

Absorption spectra pigment extract can be identified as the major pigment in bacterium is carotenoid. Most carotenoids absorbed maximally at three wavelength (Britton, 1995). The wavelength of maximum absorption and the shape of spectrum are characteristic of carotenoid chromophore (Sandmann, 2008).

Figure 3 shows an elution profile on HPLC system that corresponds to the identification for each chromatographic. HPLC has made it possible to simultaneously determine the concentrations of a wide range of carotenoids and chlorophylls and their degradation products (Bidigare et al.,2005). Peak 1, 2 , and 3 were identified as diadinoxanthin, fucoxanthin, dinoxanthin, respectively. These three peaks (Figure 4) have a maximum absorption paterns that almost the same. The differences of the three peaks are only in stereoisomer which is a compound that has the same molecular formula. Peak 4, which was the major carotenoid, was assigned as neoxanthin. Peak 5 was a minor diadinochrome. There are several another peaks that shown on HPLC chromatogram, were not identified.

HPLC analysis equipped with a PDA detector (Photo Diode Array), excess PDA detector is able to analyze the multi-wavelength and can be see absorption spectra of each peak. Pattern spectra are presented in Figure 4.

On HPLC chromatogram of pigment extract in bacterial symbiont of $C$. vaginalis showed there are only 5 of specific and main pigments based on typical peak and peak area at retention time of 9, $9.4,13.8,24$, and 43.2 minutes. These peaks identification were based on the absorption maximum of each pigment compared with literature (Table 1). Figure 5 shows the corresponding chemical structures. Results of spectrophotometer with methanol acetone reagents show that the spectral pattern formed have peak absorption at a range of wavelength of 300-600 nm (Gross, 1991).

Diadinoxantines are compounds with chemical structure $\mathrm{C}_{40} \mathrm{H}_{54} \mathrm{O}_{3}$, pigment is included in xanthophyl group 1 that normally found in diatoms and dinoflagelata. Diadinoxanthin included in the xanthophyl group because it has oxygen in ring ionon. Therefore it can be conclude that the class diadinoxanthin found as carotenoids of the CB-SP5

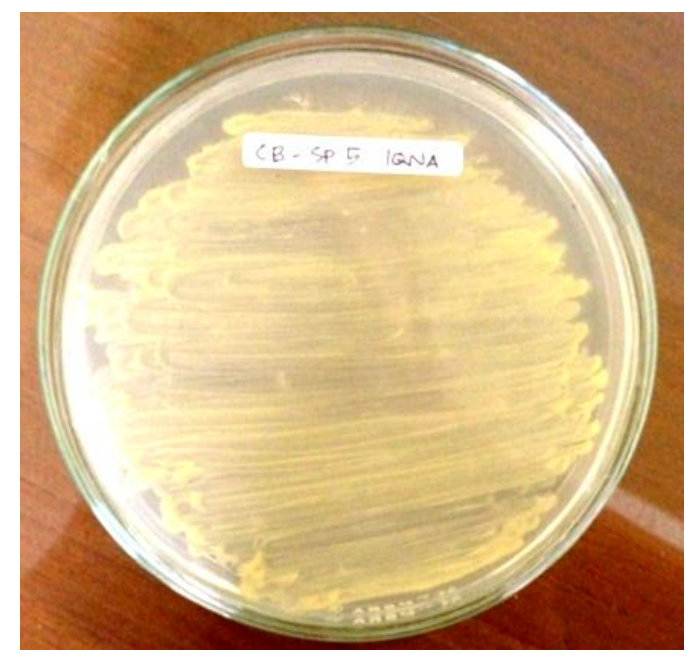

Figure 1. Pigment producing bacterium isolated from sponge sample 


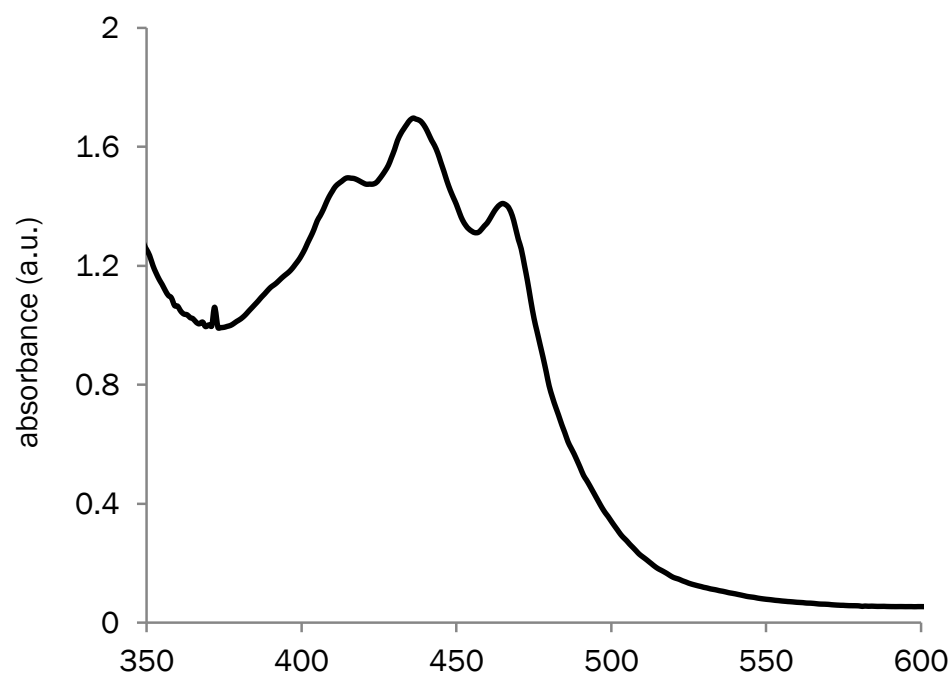

Wavelength $(\mathrm{nm})$

Figure 2. Absorption spectra pigment extract from bacterial symbiont of Callyspongia vaginalis

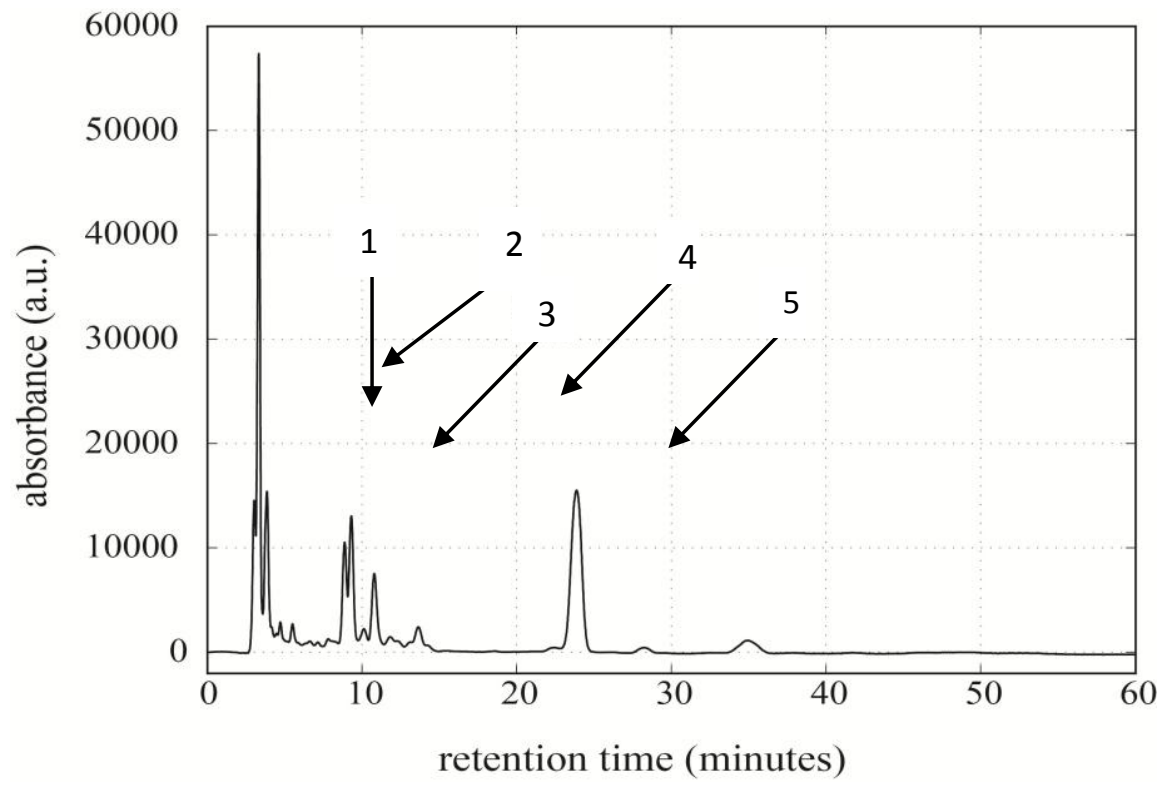

Figure 3. HPLC chromatogram of separation pigment from bacterial symbiont of $C$. vaginalis

isolate is a carotenoid of xantophyl class. Dinoxanthin, fucoxanthin, neoxanthin, are also type of xanthohyll. Diadinochrome is rearrangement product of diadinoxanthin, which found in dinoflagellate.

Many marine sponges are brilliantly colored due to the presence of carotenoids. The characteristic carotenoids in sponges are aryl carotenoids such as isorenieratene, renieratene, and renierapurpurin (Matsuno, 2001). More than twenty aryl carotenoids have been reported in sponges. Except for sea sponges, aryl carotenoids are found only in green sulfur bacteria. Therefore, aryl carotenoids in sponges are assumed to originate from symbiotic bacteria (Matsuno, 2001). Novel carotenoid sulfates having an acetylenic group, termed bastaxanthins, were isolated from the sea sponge lanthellabasta (Britton et al., 2004). Recently, a new acetylenic carotenoid was isolated from the marine sponge Prianososiros (Rogers et al., 2005). However, in the present study shows that 


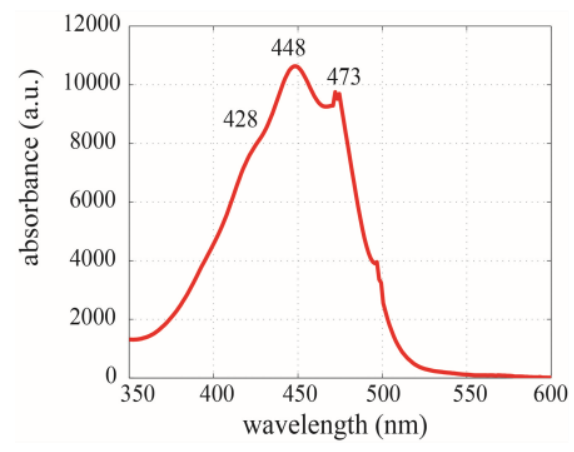

1

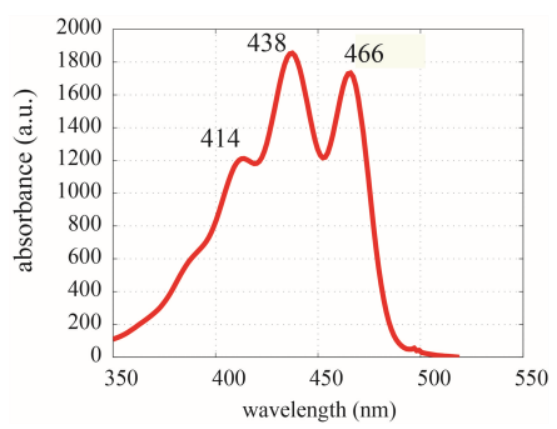

4

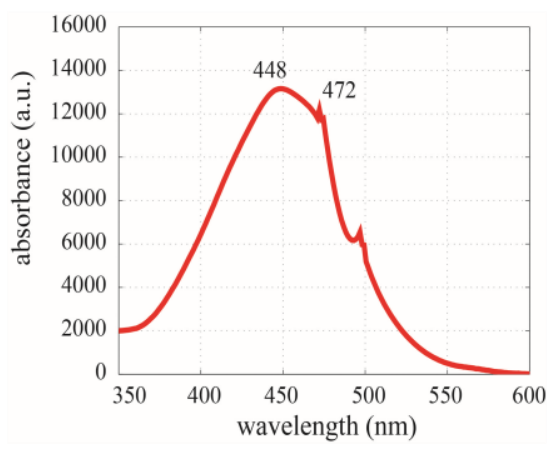

2

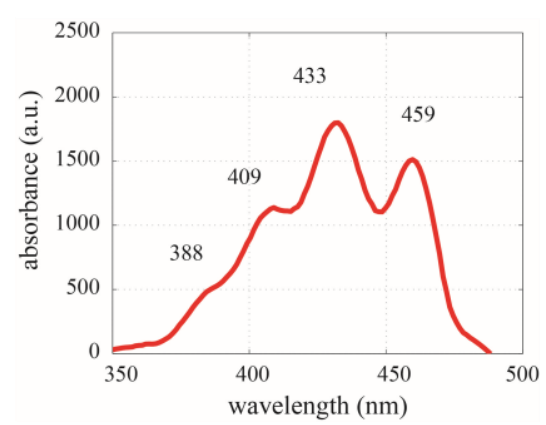

5

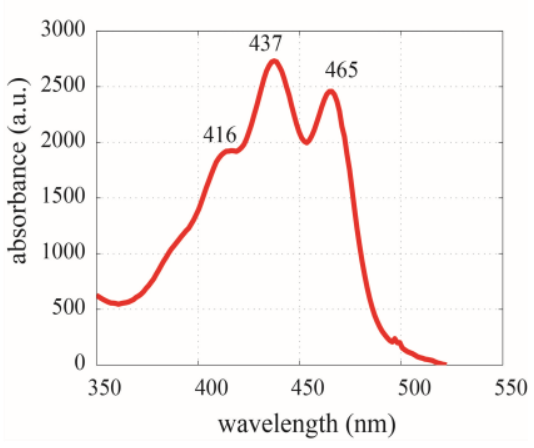

3

Figure 4. Absorption spectra of typical and main pigments diadinoxanthin (1), fucoxanthin (2), dinoxanthin(3), neoxanthin(4), diadinochrome (5)

Table 1. List of characterization of carotenoid pigments in CBSP5.

\begin{tabular}{ccll}
\hline \multirow{2}{*}{ Peak } & Retention time $(\min )$ & \multicolumn{2}{c}{ Absorption maximum $(\mathrm{nm})$} \\
\cline { 3 - 4 } & & \multicolumn{1}{c}{ Result } & Jeffrey, 1997 \\
\hline 1 & 9.0 & $428,448,473$ & $425,448,478$ \\
2 & 9.4 & 448,472 & 446,468 \\
3 & 13.8 & $416,437,465$ & $416.7,440.5,469.9$ \\
4 & 24 & $414,437,465$ & $415.1,438.5,467.1$ \\
5 & 43.2 & $409,432,459$ & $410,430.7,457.9$ \\
\hline
\end{tabular}

bacterial symbiont from sponge $C$. vaginalis did not produce the aryl carotenoids.

The present study probably indicates that pigment production is influenced by physical factors such as temperature and $\mathrm{pH}$ of the culture medium. There should be many other factors, affecting pigmentation by the bacterium such as source and concentration of nutrient component. The bacteria growing on the surface of sponges live in a highly competitive environment in which access to space and nutrients are limited (Ibhrahim et al., 2014; Slattery et al., 2001). In addition, surfaces of many marine invertebrates providing a nutrient rich habitat for heterotrophic bacteria that leading to the formation of biofilm-forming microbial communities. It has been suggested that natural products from marine invertebrates have striking similarities to metabolites of their associated microorganisms.

Amplification of the 16S rDNA was done by PCR with positive amplification of approximately 1500bp (Figure 6). Molecular identification, by two directions sequencing of the PCR product, showed that isolate CB-SP5 has the highest percentage of similarly with Psychrobacter celer strain with a 99\% level value (Table 2). According to Hagström et al., (2000), isolate which has 16S rDNA sequence 
similarity similar more than $97 \%$ can represent same species. Therefore we can conclude that isolate bacterial CB-SP5 is Psychrobacter celer species. Figure 7 shows the phylogenetic affiliation of bacterial isolate with other microorganisms.
The genus Psychrobacter was created by Juni and Heym (1986). This organism grew optimally at $25-30^{\circ} \mathrm{C}$, occurs at $\mathrm{pH} 5-0$, and in the presence of $2-3 \%(\mathrm{w} / \mathrm{v}) \mathrm{NaCl}$, which was isolated from the South Sea in Korea (Jung-Hoon et al., 2005). The
1. Diadinoxanthin

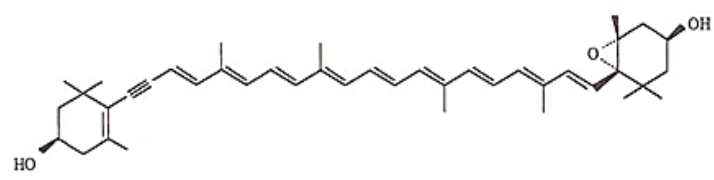

2. Fukoxanthin<smiles>CC(=O)OC1CC(=CC(C)=CC=CC(C)=CC=CC=CC(C)=CC=CC=C(C)C(=O)CC2(C)C(C)CC(O)CC2(C)C)C(C)(C)C(C)(O)C1</smiles>

3. Dinoxanthin<smiles>CC(=O)OC1CC(C)(C)C(=CC(C)=CC=CC(C)=CC=CC=C(C)C=CC=C(C)C=CC2(C)C(C)CC(O)CC2(C)C)CC1(C)C</smiles>

4. Neoxanthin

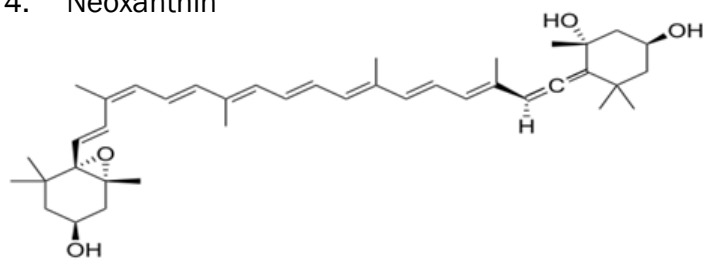

5. Diadinochrome

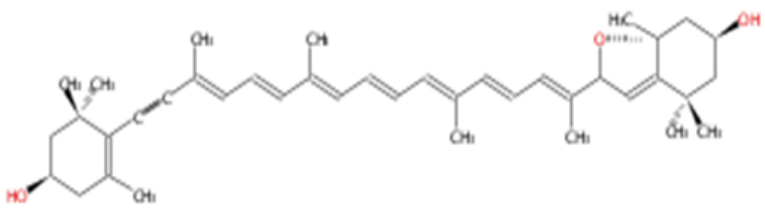

Figure 5. Structure of carotenoids produced by bacterial symbiont of C. vaginalis (Jeffrey, 1997)

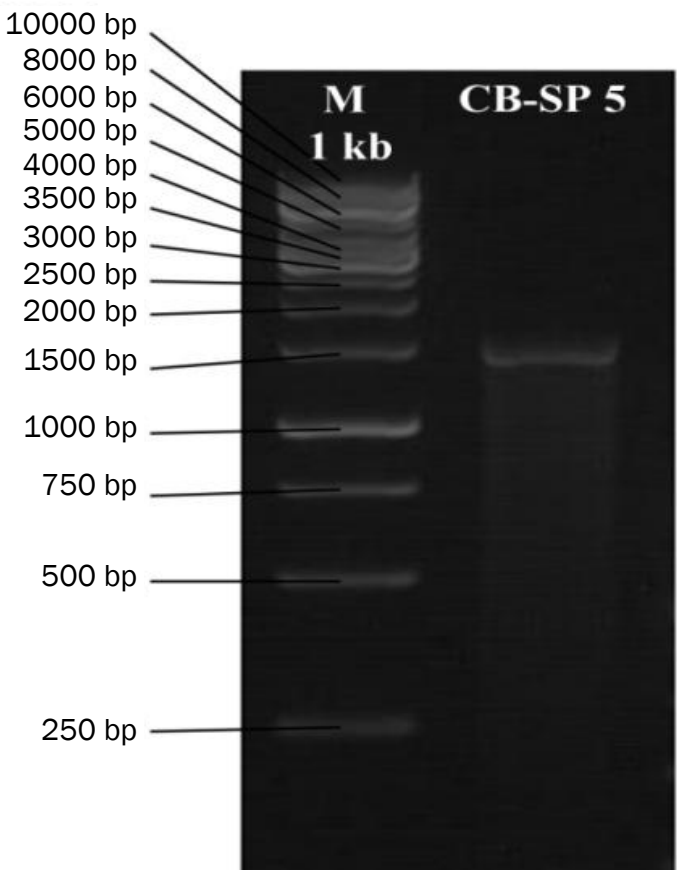

Figure 6. PCR Amplification of $16 S$ rDNA fragment. M : Marker; CBSP5: sample; bp : base pair 


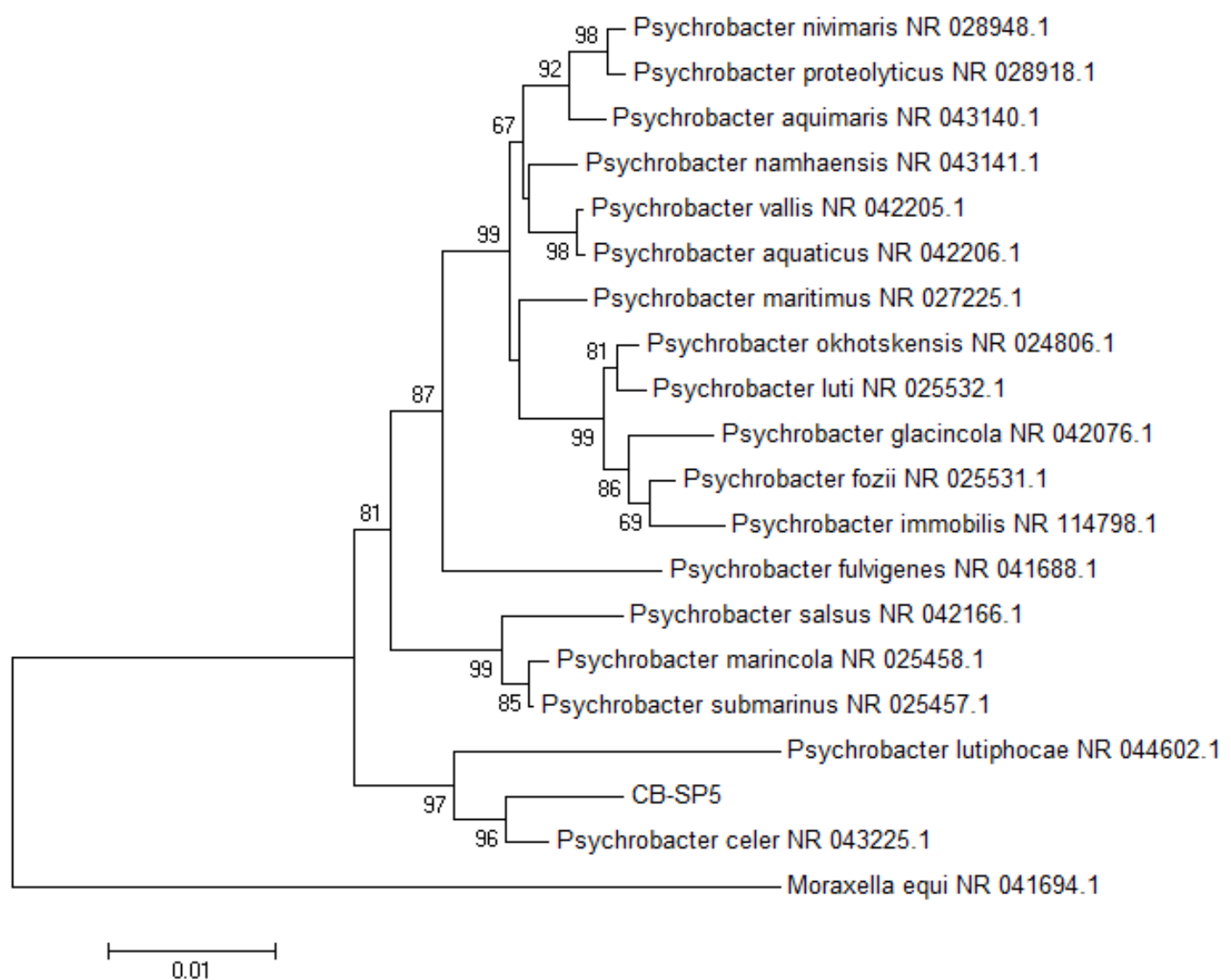

Figure 7. Phylogenetic tree based on 16S rDNA gene sequence strain CB-SP5 and representative members of related species of the genus Psychrobacter.

Table 2. Molecular identification of bacterial symbiont

\begin{tabular}{cccc}
\hline Code & Length & Closest Relative & Homology \\
\hline CB-SP5 & 1500bp & Psychrobacterceler & $99 \%$ \\
\hline
\end{tabular}

characteristics of this bacterium are Gramnegative,nonmotile bacterium, nonspore-forming, slightly halophilic bacterial strain (Jung-Hoon et al., 2005). Colonies are circular, smooth, glistening, raised, cream-colored. According to Juni and Heym (1986) that bacteria genus Psychrobacter are nonpigmented, and some species of this genus produce the black-brown pigment. However, in this study shows the result that this bacterium Psychrobacter celer CB-SP5 can produce carotenoid pigment. It is an interesting phenomenon that needs further research regarding carotenoids that are produced by the isolated bacterium symbiont of sponges.

Surveying and identifying microbial symbionts present in host invertebrates are fundamentally important in cases in which biosynthesis of a natural product. We have just begun identified the pigments as a natural products from the bacterial symbiont of Callyspongia vaginalis sponge.

\section{Conclusion}

Strain bacteria CB-SP5 which isolated from sponge Callispongia vaginalis was identified that have a homology of $98 \%$ with Psychrobacter celer NR 043225.1. By HPLC analysis, Psychrobacter celer CB-SP5 bacteria isolate contains diadinoxanthin, fucoxanthin, dinoxanthin, neoxanthin, and diadinochrome. It was suggests that the bacterial symbionts of $C$. vaginalis have potency as a crotenoid source. However, the study of determining the source of interesting and pigmentation metabolites from bacterial symbiont of sponge has rarely been demonstrated. Thus further research on the bacterial symbiont pigmentation is needed.

\section{Acknowledgments}

This work was supported by the Indonesian Ministry of Research, Technology and Higher Education through "Beasiswa Unggulan". We would also like to thank Dhanang Puspita, Paulus Damar B.M. for some of the sampling and Lia Kusmita for pigment analysis. 


\section{References}

Altschul, S.F., Madden, T.L., Schaffer, A.A., Zhang, J., Zhang, Z., Miller, W. \& Lipman, D.J.. 1997. Gapped BLST and PSI-BLAST: a new generation of protein database search programs. Nuceid Acid Res. 25:3389-3402. doi: 10.1093/nar /25.17.3389.

Abdelnasser, S.S.I. 2008. Production of carotenoids by a newly isolated marine Micrococcus sp. J. Biotech. 7 (3):469-474. doi: 10.3923/biotech. 2008.469.474.

Bidigare, R.R., Laurie, V.H. \& Charles, C.T. 2005. Analysis of Algal Pigments By High-Performance Liquid Chromatography. Academic Press. Chapter. 20:327-345.

Britton,G. 1995. Structure and properties of Carotenoids in relation to function. FASEB. J. 9(115):1551-1558.

Britton, G., Liaaen-Jensen, S. \& Pfander, H.2004. Carotenoids Hand Book; Birkhäuser: Basel, Switzerland. doi: 10.1007/978-3-0348-78364.

Burgess, J.G., Boyd, K.G., Armstrong, E., Jiang, Z., Yan, L., Breggren, M.,May, U., Pisacane, T., Granmo, A. \& Adams, D.R. 2003. The development of a marine natural productbasedantifouling paint. Biofouling. 19: 197205. doi : 10.1080/0892701031000061778.

Burton, G.W. \& Ingold, K.U., 1984. $\beta$-carotene: an unusual type of lipid antioksidant. Sci. 224: $569-573$

Cardona, V., David, A.,Scellekens,J. \& RiosVelazquez, C. 2010. Characterization of blue pigmented bacterial from Puerto Rico. Current Research, Technology and Education Topics in Appl. Microbiol. Microbial. Biotechnol.1:117123.

Cohen-Bazire, G., Sistrom, W.R. \& Stainer, R.Y. 1957. Kinetic Studies of Pigment Synthesis by Nonsulfur Purple Bacteria. J. Cell. Comp. Physiol. 49:25-68.

Cruickshank, S.S., Ozgul, A., Zumbach., S., \& Schmidt, B.R. 2016. Quantifying population declines based on presence-only records for red-list assessments. Conversation Biology. 30(5):1112-1121. doi: 10.1111/cobi.12688.

Di Mascio, P., Kaiser, S. \& Sies, H., 1989. Lycopene As The Most Efficient Biological Carotenoids Singlet Oxygen Quencher. Arch. Biochem.
Biophys. 274:532-538. doi: 10.191 6/0003986198990467-0.

Du, H.L., Jiao, N.Z., Hu, Y.H. \& Zeng, Y.H. 2006. Diversity And Distribution Of Pigmented Heterotrophic Bacteria In Marine Environments. FEMS Microbiol Ecol. 57(1):92-105. doi: 10.1111/j.1574-6941.2006.00090.x.

Duckworth, A.R., Bruck, W.M., Janda, K.E., Pitts, T.P., \& McCarthy, P.J. 2006. Retention efficiencies of the coral reef sponges Aplysinalacunosa, Callyspongia vaginalis and Niphates digitalis determined by Coulter counter and plate culture analysis. Mar Biol. Res.2(4):243-248.

Gross, J. 1991. Pigment in vegetables. Van Natrand Reinhold, New York. 351pp. doi: 10.1007/9781-4615-2033-7.

Hagström, A., Jarone, P. \&Ulla L.Z. 2000. Biogeographical Diversity Among Marine Bacteria plankton. Aquat. Microb. Ecol. 21:231244. doi: 10.3354/ame021231.

Harashima, K. 1989. Carotenoids, quinones and other lipids. Japan Scienti. Soc. Press. Tokyo.125-148.

Hentschel, U., Hpke, J., Horn, M., Fiedrich, A.B., Wagner, M. \& Hacker, J. 2002. Molecular evidence for a uniform icrobial community in spongs from different oceans. Appl. Environ. Microbiol. 68:4431-4440. doi: 1128/AEM.68. 9.4431-4440-2002.

Ibrahim, D., Teh, F.N., Jain, K. \& Sheh-Hong, L. 2014. Prodigiosin an antibacterial red pigment produced by Serratiamarcescens IBRL USM 84 associated with a marine sponge Xestospongia testudinaria. J. Appl. Pharmaceut. Sci.4(10):16. doi: 10.7324/JAPS.2014.40101.

Imhoff, J.F. \& StÖhr, R. 2003. Sponge-associated bacteria: general overview and special aspects of bacteria associated with Halichondria panacea. Proc. Natl. Acad. Sci USA. 82:69556959.

Juni, E. \& Heym, G.A. 1986. Psychrobacterimmobilis gen. nov., sp. nov.: genospecies composed of gram-negative, aerobic, oxidasepositive coccobacilli. Int. J. Syst. Bacteriol. 36:388-391.

Jung-Hoon, Y., Choong-Hwan, L., So-Jung, K. \& TaeKang, O. 2005. Psychrobactercelersp. nov., isolated from sea water of the South Sea in Korea.Int. J. Syst. Evol. Microbiol. 55:18851890. doi: 10.1099/ijs.0.63682-0. 
Jeffrey, S.W., Mantoura, R.F.C., \& Wright,S.W. 1997. Phytoplankton Pigments in Oceanography. Guidelines to Modern Method. UNESCO Publishing, Paris. 661p. doi: 10.1023/A:10071 68802525.

Kuki, M., Nagae, H., Cogdell, R.J., Shimida, K. \& Koyama, Y. 1994. Solvent effect on spheroidene in nonpolar and polar solutions and the environment of spheroidene in the light-harvesting complexes of Rhodobacter sphaeroides 2.4 .1 as revealed by the energy of the $1 \mathrm{~A}^{-}$gand $1 \mathrm{~B}^{+} \mathrm{u}$ absorption and the frequencies of the vibrinically coupled $\mathrm{C}=\mathrm{C}$ stretching Raman lines in the $1 \mathrm{~A}^{-} \mathrm{g}$ and $2 \mathrm{~A}^{-\mathrm{g}}$ states. Photochem Photobiol. 59:116-124.

Long, R.A. \& Azam, F. 2001. Antagonistic Interactions among Marine Pelagic Bacteria. Appl Environ Microbiol. 67 (11): 4975-4983. doi: 10.1128/ AEM.67.11.4975-4983.2001.

Madigan, M.T., Martinko, J.M. \& Paker, J. 2000. Brock Biology of Microorganisms $9^{\text {th }}$ Edition. Prentice Hall. New Jersey. doi: 10.1016/S0301-9268 (99)00013-3.

Maeda, H., Masashi, H., Tokute, S., Katsura, F. \& Kazuo, M. 2005. Fucoxanthin from edible Seaweed, Undaniria Pinnatifida, Shows Antiobesity Effect Trough UCP1 Expression in White Adipose Tissues. Biochem. Biophy. Res. Comm. 332:393-397. doi: 10.1016/j.bbrc.20 05.05.002

Marit, H.S., Kjell, D.J., Geir, K.A., Svein, V., Trond, E.E. \& Per, B. 2010. Isolation and characterization of marine pigmented bacteria from Norwegian Coastal waters and screening for carotenoids with UVA-Blue light absorbing properties. J Microbiol. 48(1): 16-23.

Matsuno, T. 2001. Aquatic animal carotenoids. Fish. Sci.67:771-789.

Nugraheni, SA., Khoeri, M.M., Kusmita, L., Widyastuti, Y. \& Radjasa, O.K. 2010. Characterization of Carotenoid Pigments from Bacterial Symbionts of Seagrass Thalassiahemprichii. J. Coast. Dev. 14(1):5160.

Radjasa, O.K. \& Sabdono, A. 2003. Screening of secondary metabolite-producing bacteria associated with corals using 165 rDNA-based approach. J. Coast. Dev. 7:11-19
Radjasa, O.K. \& Sabdono, A. 2009. Bacterial symbionts of reef's invertebrates as a sustainable source of marine natural products.Curr. Res. Bacteriol.2(1):7-13.

Rashid, M.M., Md. Fakruddin, Reaz, M.M., Fatema, K. \& Md. Alimuddin C. 2014. Anti-Bacterial Activity of Pigments Isolated From Pigmentforming Soil Bacteria. Brith. J. Pharmaceutic. Res.4(8): 880-894.

Rogers, E.W. \& Molinski, T.F.2005. A cytotoxic carotenoid from the marine sponge Prianososiros. J. Nat. Prod. 68 450-452.doi: 10.1021/np0497797.

Sandman, G. 2008. C35-apocarotenoid in the yellow mutant Neurosporacrassa YLO.Photochem. 69:2886-2890.

Satfsnes, M.H., Josefsen, K.D., Andersen, G.K., Valla, S., Ellingsen, T.E. \& Bruheim, P. 2010. Isolation and Characterization of Marine Pigmented Bacteria from Norwegian Coastal Waters and Screening for Carotenoids with UVA-Blue Light Absorbing Properties. The J. Microbial. 48(1): 16-23. doi: 10.1007/s12275-009-0118-6.

Slattery, M, Rajbhandari, I. \& Wesson, K. 2001. Competition-mediated antibiotic induction in the marine bacterium Streptomyces tenjimariensis. Microb Ecol. 41:90-96. doi : $10.1007 / \mathrm{s} 002480000084$.

Takaichi, S., Shimada, K., \& Ishidsu, J. 1990. Carotenoids from the aerobic photosynthetic bacterium, Erythrobacter longus: $\beta$-Carotene and its hydroxyl derivatives. Arch. Microbiol. 153:118-122. doi: 10.1007/BF00247807.

Unson, M.D., Holland, N.D., \& Faulkner, D.J. 1994. A brominatedsecondary metabolite synthesized by the cyanobacterial symbiont of amarine sponge and accumulation of the crystalline metabolite in thesponge tissue. Mar. Biol. 119:1-11. doi: 10.1007/BF00350100.

Walsh, P.S., David, A.M. \& Rusell, H. 2013. Chelex 100 as a Medium for Simple Extraction of DNA for PCR Based Typing from Forensic Material. Biotech. 54:3.

Walters, K.D. \& Pawlik, J.R. 2005. Is there a Tradeoff between wound-heling and chemical defences among Caribbean reef sponges. Integr.. Comp. Biol. 45:352-358. doi: 10.1093/icb/45.2.352. 
Wusqy, N.K., Limantara, L. \& Karwur, F.F. 2014. Exploration, Isolation and Quantification of $\beta$ carotene from Bacterial Symbiont of
Acroporasp. Microbiol. Indo. 8:58-64. doi: 10.5454/mi.8.2. 